\title{
CHROMOSOME EVOLUTION AND DNA VARIATION IN CREPIS
}

\author{
R. N. JONES and L. M. BROWN \\ Department of Agricultural Botany, University College of Wales, Aberystwyth
}

Received 19.ix.75

\begin{abstract}
SUMMARY
There is wide variation in chromosome size and nuclear DNA amount between the 22 species studied within the genus Crepis. The changes in DNA amount involve all, or most of, the chromosomes within species complements, but structural rearrangements due to inversions and interchanges have made the distribution of changes somewhat unequal. There is an evolutionary reduction in the amount of DNA with the most primitive perennial species having higher DNA values than the more advanced annual species. The advanced species have more chromosomes with median centromeres than the primitive species and show increased symmetry. Nuclear DNA amount is positively correlated with both seed size and pollen grain size.
\end{abstract}

\section{InTRODUCTION}

IT has been known for a long time that large differences exist between the chromosome complements of different species both in terms of the number and size (volume) of chromosomes (Blackburn, 1933; Darlington, 1937). Quantitative variation in nuclear genetic material, which is now assessed in more precise and meaningful terms by Feulgen microspectrophotometry, turns out to be very large indeed (Bennett, 1972; Rees and Jones, 1972; Sparrow, Price and Underbrink, 1972; Cheng and Grant, 1973; Miksche and Hotta, 1973; Cullis and Schweizer, 1974; Goepfert, 1975).

The questions posed by this problem of genome amplification, which concern the origins, range and evolutionary significance of DNA differences, have as much to do with closely related species within a genus, like the genus Crepis, as they have to do with the wider issues involving major phyla of plants or animals. In fact a study of the DNA variation between closely related diploids within a genus provides a useful approach because there exists the possibility of making species hybrids and of tracing the path of chromosome evolution from an early stage of divergence. The genus Crepis is admirably suited for such an analysis because so much is already known about the phylogeny and cytology of many species. Crepis is the second largest genus in the tribe Cichorieae of the Compositae. Members of the genus can be found throughout the world, although the majority occur in Europe and Asia. There are more than 196 known species, 113 of which have been studied cytologically. All the species are herbs but only 40 of them are annual species; the vast majority are perennials (Babcock, 1947). The low basic chromosome number combined with the distinctive morphology of the members of the complements make Crepis an amenable genus for cytological study. The present investigation is cytological in nature seeking to quantify and investigate the structural basis of variation in chromosome size and nuclear DNA, to relate changes in DNA amount to the taxonomic 
classification of the species, to ascertain if there are any predictable developmental consequences of DNA variation and to provide information on which to base future biochemical analyses of genome organisation.

\section{Materials AND methods}

\section{(i) Materials}

Seeds of the Crepis species were obtained from a number of European Botanic Gardens which are listed in table 1. The species are listed in the table according to the classification of Babcock (1947) with their chromosome numbers and ploidy levels.

\section{TABLE 1}

Crepis species list

\begin{tabular}{|c|c|c|c|}
\hline Section* & Species & $2 n$ & Source \\
\hline 1 & C. sibirica & 10 & $\begin{array}{l}\text { Hortus Botanicus Universitatis, Oulu, } \\
\text { Finland }\end{array}$ \\
\hline 4 & C. aurea & 10 & The Botanic Garden, Cambridge, England \\
\hline 5 & C. lapsanoides & 12 & $\begin{array}{l}\text { Estação Agronomica Nacional, Oeiras, } \\
\text { Portugal }\end{array}$ \\
\hline 5 & C. mollis & 12 & Botanischer Garten, Bremen, Germany \\
\hline 6 & C. pontana & 10 & $\begin{array}{l}\text { Botanischer Garten der Universität, Bern, } \\
\text { Switzerland }\end{array}$ \\
\hline 6 & C. grandiftora (conyzaefolia) & 8 & $\begin{array}{l}\text { Station Nationale d'Essais de Semences } \\
\text { (service botanique), Versailles, France }\end{array}$ \\
\hline 6 & C. blattarioides & 8 & $\begin{array}{l}\text { Jardin Botanique de la Ville, Dijon, } \\
\text { France }\end{array}$ \\
\hline 10 & C. biennis & 40 & Botanischer Garten, Bremen, Germany \\
\hline 10 & C. pannonica & 8 & $\begin{array}{l}\text { Botanischer Garten der Pädogogischen, } \\
\text { Hochschule, Potsdam, Germany }\end{array}$ \\
\hline 14 & C. tectorum & 8 & Le Jardin Botanique, Besançon, France \\
\hline 19 & C. palaestinia & 8 & $\begin{array}{l}\text { University Botanical Garden, Uppsala, } \\
\text { Sweden }\end{array}$ \\
\hline 19 & C. pulchra & 8 & $\begin{array}{l}\text { Grădina Botanica Universitǎtii, Cluj, } \\
\text { Romania }\end{array}$ \\
\hline 20 & C. alpina & 10 & Le Jardin Botanique, Besançon, France \\
\hline 20 & C. rubra & 10 & $\begin{array}{l}\text { Jardin et Institut de Botanique de } \\
\text { L'Universite de Liege, Liege, Belgium }\end{array}$ \\
\hline 20 & C. foetida & 10 & $\begin{array}{l}\text { Estação Agronomica Nacional, Oeiras, } \\
\text { Portugal }\end{array}$ \\
\hline 23 & C. dioscoridis & 8 & Royal Botanic Gardens, Kew, England \\
\hline 23 & C. zacintha & 6 & $\begin{array}{l}\text { University Botanical Garden, Uppsala, } \\
\text { Sweden }\end{array}$ \\
\hline 24 & C. capillaris & 6 & $\begin{array}{l}\text { Grădina Botanica Universitǎtii, Cluj, } \\
\text { Romania }\end{array}$ \\
\hline 24 & C. neglecta & 8 & $\begin{array}{l}\text { Institute of Rural Science, Aberystwyth, } \\
\text { Wales }\end{array}$ \\
\hline 25 & C. canariensis (lowei) & 8 & The Botanical Garden, Oslo, Norway \\
\hline 25 & C. vesicaria & 8 & $\begin{array}{l}\text { Jardin Botanique de la Ville, Dijon, } \\
\text { France }\end{array}$ \\
\hline 25 & C. taraxacifolia & 8 & Le Jardin Botanique, Besançon, France \\
\hline 26 & C. setosa & 8 & Botanischer Garten, Bremen, Germany \\
\hline- & C. laciniata & 8 & The Botanical Garden, Oslo, Norway \\
\hline - & C. bulbosa & 18 & $\begin{array}{l}\text { Institute Botanique de L'Université, } \\
\text { Coimbra, Portugal }\end{array}$ \\
\hline
\end{tabular}

* Classification according to Babcock, 1947. 


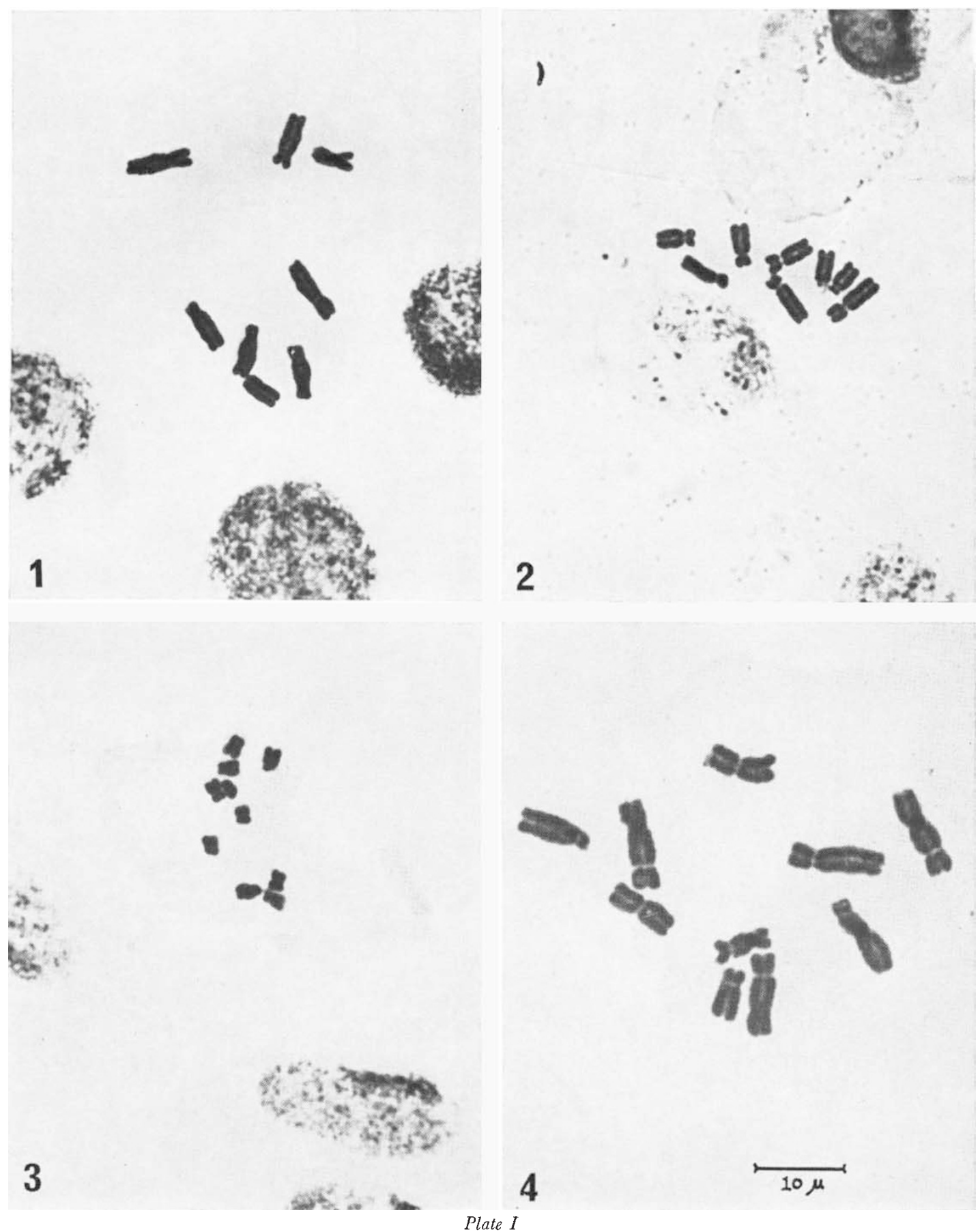

FIG. 1.-Metaphases in root tip cells of: 1. Crepis grandiflora, 2. C. laciniata, 3. C. aurea, 4. C. pontana. 


\section{(ii) Methods}

(a) Chromosome volume determinations. Seeds were germinated on moist filter paper in disposable plastic petri dishes. Crepis palaestinia seeds were included in each group as a standard to enable comparisons to be made between individual groups. Mean values could thus be corrected against the standard where the standard varied between experiments. Excised root tips of 4-5 days old seedlings were pretreated for 3 hours with a 0.2 per cent solution of colchicine. After fixation for at least 2 hours in $3: 1$ alcohol/acetic acid the roots were hydrolysed for 6 minutes in $1 \mathrm{~N} \mathrm{HCl}$ at $60^{\circ} \mathrm{G}$ and then stained for 20 minutes in Feulgen solution. Measurements were made with a Vickers moving scale micrometer eyepiece under an oil-immersion lens. Cells were selected at metaphase of c-mitosis, in which separation of the chromatids had just begun. The total chromosome volume per cell was calculated on the assumption that chromatids are cylindrical, using the formula Volume $=2 L \times \pi r^{2}$, where $L$ is the total chromosome length, and $r$ the average radius of a chromatid, calculated from at least four measurements taken at random.

(b) Nuclear DNA estimations. Species were handled in batches of not more than four at a time, to enable critical timing to be achieved. Root meristems from seeds of Allium cepa were included in each group of species as a standard, and received identical treatment at each stage. The results of individual experiments could thus be weighted according to whether the values for the standard species were higher or lower than in the initial experiment. Roots of 3-day-old seedlings grown in petri dishes were fixed in $3: 1$ alcohol/acetic acid for 2 hours and then stained according to the schedule of McLeish and Sunderland, 1961. Quantitative measurements were made on a Vickers M85 scanning microdensitometer, at a wavelength of $565 \mathrm{~m} \mu$. One root from each of two seedlings per species was prepared and $202 \mathrm{C}$ or early interphase nuclei were measured.

(c) Pollen grain size determination. Heads were collected from two plants of each species growing in a cold greenhouse and fixed in Carnoys fluid. Pollen grains were obtained from flowers just prior to stigma emergence, mounted in acetocarmine and measured with the Vickers moving scale micrometer eyepiece under a $\times 100$ oil-immersion lens. Only stainable pollen was measured; the outer walls providing the limit of measurement.

(d) Seed size. Ripe seeds were stored for several months in a warm room to allow moisture contents to stabilise at a low level. Fifty seeds per species were weighted and their mean mass determined.

(e) Interspecific hybridisation. The emasculation technique described by Babcock and Collins (1920) was used for some crosses, but most were performed by a simple transference of pollen. As some Crepis species have a degree of self-fertility the progeny were screened cytologically at the seedling stage for selfed individuals.

\section{Results}

\section{(i) The range of nuclear variation}

(a) Chromosome dimensions. The total chromosome lengths, chromatid widths and calculated chromosome volumes are summarised in table 2. 
The data represent eight replicates, i.e. eight cells, taken from at least two different seedlings. The variation in chromosome size is also illustrated by the species chromosome complements shown in fig. 1. Within each basic chromosome number group there is a large variation in volume representing a 3.6-fold difference in the 8-chromosome group and a 13-fold difference in the 10-chromosome group. Overall the total chromosome volume varies 13-fold. These data, in terms of relative chromosome lengths, are in agreement with the camera lucida data obtained by Mann (1925).

TABLE 2

Chromosome dimensions and calculated chromosome volumes in Crepis species

\begin{tabular}{clccc}
$\begin{array}{c}\text { Basic } \\
\text { chromosome } \\
\text { number }\end{array}$ & \multicolumn{1}{c}{$\begin{array}{c}\text { Species } \\
3\end{array}$} & $\begin{array}{c}\text { Total } \\
\text { chromosome } \\
\text { length } \mu\end{array}$ & $\begin{array}{c}\text { Average } \\
\text { chromatid } \\
\text { width } \mu\end{array}$ & $\begin{array}{c}\text { Chromosome } \\
\text { volume } \mu \mu\end{array}$ \\
& C. capillaris & $31 \cdot 85$ & $0 \cdot 88$ & $38 \cdot 68$ \\
4 & C. zacintha & $17 \cdot 76$ & $0 \cdot 77$ & $16 \cdot 23$ \\
& C. pulchra & $59 \cdot 84$ & $1 \cdot 06$ & $105 \cdot 82$ \\
& C. palaestinia & $71 \cdot 73$ & $0 \cdot 94$ & $98 \cdot 86$ \\
& C. grandifiora & $59 \cdot 44$ & $0 \cdot 99$ & $91 \cdot 32$ \\
& C. dioscoridis & $52 \cdot 76$ & $0 \cdot 89$ & $65 \cdot 02$ \\
& Species X & $38 \cdot 23$ & $1 \cdot 01$ & $59 \cdot 33$ \\
& C. blattarioides & $45 \cdot 85$ & $0 \cdot 90$ & $58 \cdot 15$ \\
& C. laciniata & $35 \cdot 88$ & $0 \cdot 88$ & $42 \cdot 16$ \\
& C. tectorum & $32 \cdot 68$ & $0 \cdot 88$ & $40 \cdot 53$ \\
& C. taraxacifolia & $36 \cdot 37$ & $0 \cdot 83$ & $38 \cdot 48$ \\
& C. neglecta & $36 \cdot 63$ & $0 \cdot 79$ & $34 \cdot 23$ \\
& C. canariensis & $35 \cdot 86$ & $0 \cdot 79$ & $29 \cdot 21$ \\
& C. setosa & $27 \cdot 09$ & $0 \cdot 84$ & $170 \cdot 18$ \\
& C. biennis (8x) & $163 \cdot 90$ & $0 \cdot 82$ & $160 \cdot 90$ \\
& C. sibirica & $73 \cdot 26$ & $1 \cdot 16$ & $44 \cdot 29$ \\
& C. alpina & $31 \cdot 49$ & $0 \cdot 95$ & $35 \cdot 15$ \\
& C. aurea & $34 \cdot 84$ & $0 \cdot 81$ & $29 \cdot 56$ \\
& C. rubra & $37 \cdot 25$ & $0 \cdot 72$ & $29 \cdot 13$ \\
& C. foetida & $23 \cdot 66$ & $0 \cdot 89$ & $13 \cdot 00$ \\
Species Y & $23 \cdot 93$ & $0 \cdot 60$ & $12 \cdot 79$
\end{tabular}

(b) Nuclear DNA variation. Estimates of nuclear DNA amounts for 25 species are shown in table 3. 2C refers to the amount of DNA present in the nucleus of a meristematic cell at telophase or shortly after. The mean values were obtained from the 10 lowest readings amongst the 20 nuclei presumed to be $2 \mathrm{G}$. This minimises the risk of including intermediary values between $2 \mathrm{G}$ and $4 \mathrm{G}$. Analyses of variance show that there are significant differences between diploids in each basic chromosome number group. A three-fold difference is apparent in the 8-chromosome group $(\mathbf{P}<0.001)$ and a 10-fold difference in the 10-chromosome group $(\mathbf{P}<0.001)$. The data show also that chromosome number alone is not a reliable guide to DNA amount. Therefore a proportion of the variation in DNA amount must be attributed to changes within chromosome complements. Several species in the 8-chromosome group have higher DNA amounts than some of the species in the 10-chromosome group. Excluding the polyploid species C. biennis, there is an overall difference in DNA amounts of nine times, which is equivalent to a ploidy range of $2 x$ to $18 x$. There is no evidence for the existence of an intergral series of DNA values of the kind found by Martin (1968) in Vicia. 
TABLE 3

Mean DNA values in $2 C$ nuclei of Crepis species

\begin{tabular}{|c|c|c|c|c|}
\hline \multirow{2}{*}{$\begin{array}{c}\text { Basic } \\
\text { chromosome } \\
\text { number }\end{array}$} & \multirow[b]{2}{*}{ Species } & \multicolumn{2}{|c|}{ DNA values } & \multirow[b]{2}{*}{$\begin{array}{c}\text { Mean DNA } \\
\text { value }\end{array}$} \\
\hline & & Rep. 1 & Rep. 1 & \\
\hline \multirow[t]{2}{*}{3} & C. capillaris & 12.99 & $13 \cdot 14$ & $13 \cdot 07$ \\
\hline & C. zacintha & $6 \cdot 45$ & $5 \cdot 48$ & 5.97 \\
\hline \multirow[t]{13}{*}{4} & C. grandiflora & 35.49 & $37 \cdot 04$ & $36 \cdot 26$ \\
\hline & C. palaestinia & 35.45 & $34 \cdot 63$ & 35.04 \\
\hline & C. dioscoridis & $38 \cdot 13$ & $30 \cdot 57$ & $34 \cdot 35$ \\
\hline & C. pulchra & $26 \cdot 22$ & $34 \cdot 18$ & $30 \cdot 20$ \\
\hline & C. blattarioides & $26 \cdot 14$ & $25 \cdot 39$ & $25 \cdot 77$ \\
\hline & C. laciniata & $20 \cdot 50$ & $19 \cdot 10$ & $19 \cdot 80$ \\
\hline & C. tectorum & $20 \cdot 04$ & $17 \cdot 87$ & 18.96 \\
\hline & Species X & $19 \cdot 07$ & $17 \cdot 28$ & $18 \cdot 18$ \\
\hline & C. taraxacifolia & $17 \cdot 10$ & 17.91 & $17 \cdot 50$ \\
\hline & C. neglecta & $16 \cdot 04$ & $16 \cdot 38$ & $16 \cdot 21$ \\
\hline & C. canariensis & $14 \cdot 31$ & $15 \cdot 64$ & 14.97 \\
\hline & C. setosa & $12 \cdot 37$ & $13 \cdot 66$ & $13 \cdot 02$ \\
\hline & C. pannonica & $12 \cdot 09$ & $10 \cdot 84$ & $11 \cdot 46$ \\
\hline \multirow[t]{8}{*}{5} & C. biennis $(8 x)$ & $49 \cdot 21$ & $40 \cdot 93$ & $46 \cdot 97$ \\
\hline & C. sibirica & $34 \cdot 80$ & $45 \cdot 69$ & $40 \cdot 25$ \\
\hline & C. pontana & 38.85 & 37.93 & $38 \cdot 39$ \\
\hline & C. alpina & $17 \cdot 22$ & $16 \cdot 33$ & $16 \cdot 78$ \\
\hline & C. rubra & $14 \cdot 33$ & $17 \cdot 55$ & 15.94 \\
\hline & C. aurea & $13 \cdot 61$ & $14 \cdot 38$ & $14 \cdot 00$ \\
\hline & C. foetida & $11 \cdot 76$ & $10 \cdot 15$ & $10 \cdot 96$ \\
\hline & Species Y & $4 \cdot 75$ & $4 \cdot 68$ & $4 \cdot 72$ \\
\hline 6 & C. lapsanoides & $31 \cdot 08$ & $31 \cdot 01$ & $31 \cdot 05$ \\
\hline 9 & C. bulbosa & 4.09 & $5 \cdot 71$ & 4.90 \\
\hline
\end{tabular}

(c) Chromosome volume and DNA amount. A graph of DNA amounts plotted against chromosome volumes (fig. 2) shows that there is a direct correlation between them. The regression is curvilinear and highly significant $(\mathrm{P}<0 \cdot 01)$. At low DNA values there is a parallel increase in nuclear DNA with increasing chromosome size but there is a fall-off in the rate of increase in chromosome volumes as the DNA reaches high values. McLeish and Sunderland (1961) demonstrated, in a wide range of species, the positive correlation between chromosome size (volume) and nuclear volume, and that nuclear volume falls off at high DNA values.

\section{(ii) Distribution of chromosome changes within complements}

(a) Chromosome length variation. Such large differences in DNA amount as those in Crepis could pose problems of genic balance between different chromosomes of the complement. Widespread distribution of the changes amongst all the chromosomes of the complement is one way of preserving this balance. Given that nuclear DNA amount and chromosome size are positively correlated we can make some assessment of the distribution of the DNA changes between the chromosomes of the complement. If the changes in DNA amount were restricted to a single pair of homologous chromosomes an increase in variance of chromosome length would be expected with an increase in DNA amount. An absence of such a correlation would indicate that the changes in DNA were distributed to all or most of the chromosomes. 


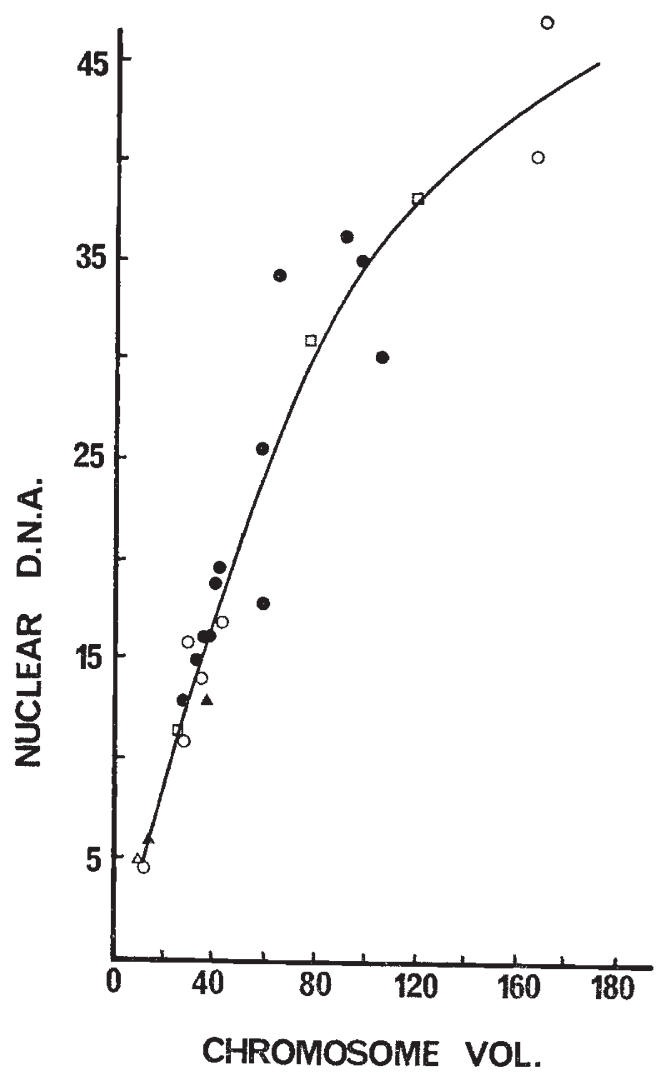

Fig. 2.-Mean nuclear DNA content (in arbitrary units) plotted against total chromosome volume (in cubic microns) in 25 species of Crepis. $\Delta x=3,0 x=4, \bigcirc x=5, \Delta x=9$, $\square$ DNA values only.

Mean lengths of the chromosome pairs for 17 species are given in table 4 along with the variances of the means. The data represent the means of four replicates. Data are omitted for the octoploid species $C$. biennis, the two unidentified species and $C$. bulbosa, the classification of which is in some doubt. The latter was listed by Babcock and Stebbins (1943) as Aetheorrhiza bulbosa. As the mean chromosome lengths and the variances are positively correlated $(r=0.76, \mathrm{P}<0.001)$ the variances were adjusted by dividing each by the appropriate mean, thus obtaining a coefficient of variation. The regression analysis of variance of nuclear DNA amount against this coefficient is not significant for either of the two groups of species. Therefore it would seem reasonable to conclude that, in those species studied, changes in the amount of nuclear DNA are distributed to all or most of the chromosomes in the complement. Although changes are allocated in this way they may not be consistent for all the chromosomes. Moreover, chromosomal rearrangements by deletions, duplications or translocations may make the distributions discontinuous.

(b) Crepis hybrids. Hybrids between Crepis species may provide evidence as to the distribution of changes in DNA amount both in terms of chromosome rearrangements and also duplication or deletion of chromosome 
TABLE 4

Chromosome lengths in Crepis species. Mean lengths of chromosome pairs in microns

\begin{tabular}{|c|c|c|c|}
\hline Species & Mean length & $\begin{array}{l}\text { Variance of } \\
\text { length }\end{array}$ & $\begin{array}{l}\text { Corrected } \\
\text { variance }\end{array} \frac{V x}{x}$ \\
\hline \multicolumn{4}{|l|}{$x=3$} \\
\hline C. capillaris & $4 \cdot 55$ & $2 \cdot 05$ & 0.45 \\
\hline C. zacintha & $2 \cdot 73$ & 0.79 & $0 \cdot 29$ \\
\hline \multicolumn{4}{|l|}{$x=4$} \\
\hline C. palaestinia & $9 \cdot 25$ & $4 \cdot 01$ & 0.43 \\
\hline C. pulchra & $7 \cdot 75$ & $2 \cdot 56$ & 0.33 \\
\hline C. grandiflora & $7 \cdot 37$ & $1 \cdot 13$ & $0 \cdot 15$ \\
\hline C. dioscoridis & $6 \cdot 50$ & 0.71 & $0 \cdot 11$ \\
\hline C. tectorum & 4.99 & 1.29 & $0 \cdot 26$ \\
\hline C. blattarioides & $4 \cdot 71$ & $1 \cdot 34$ & $0 \cdot 28$ \\
\hline C. taraxacifolia & $4 \cdot 13$ & 0.44 & $0 \cdot 11$ \\
\hline C. laciniata & 4.04 & 0.37 & 0.09 \\
\hline C. neglecta & $4 \cdot 02$ & $0 \cdot 60$ & $0 \cdot 15$ \\
\hline C. canariensis & 3.55 & $0 \cdot 12$ & 0.03 \\
\hline C. setosa & $2 \cdot 79$ & 0.94 & $0 \cdot 34$ \\
\hline \multicolumn{4}{|l|}{$x=5$} \\
\hline C. sibirica & $6 \cdot 63$ & $2 \cdot 73$ & $0 \cdot 41$ \\
\hline C. rubra & 3.58 & $1 \cdot 33$ & $0 \cdot 37$ \\
\hline C. aurea & 3.39 & $0 \cdot 26$ & 0.08 \\
\hline C. alpina & 3.28 & 1.21 & 0.37 \\
\hline C. foetida & $2 \cdot 22$ & 0.38 & $0 \cdot 17$ \\
\hline
\end{tabular}

segments. Two of the hybrids used in the present study have not previously been described: $C$. laciniata $(2 n=2 x=8) \times C$. albida $(2 n=2 x=10)$ and C. laciniata $\times C$. aurea $(2 n=2 x=10)$. Pachytene analysis of these hybrids did not reveal the presence of large unpaired loops or overlaps due to duplications of the kind reported in Allium hybrids (Jones and Rees, 1968). However, the complicated configurations obtained due to the presence of multiple translocations and inversions make the position obscure, added to which is a cytologically less amenable pachytene chromosome phenotype than is generally observed in the parental, non-hybrid species. The difference in size between the parental complements is illustrated at meiotic metaphase for the hybrids $C$. laciniata $\times C$. aurea and $C$. neglecta $(2 n=2 x=8) \times$ $C$. capillaris $(2 n=2 x=6)$ shown in fig. 3 . In the $C$. laciniata $\times C$. aurea hybrid the chromosomes of $C$. laciniata are 20 per cent larger by volume than those of $C$. aurea. It is not necessarily the case that every $C$. laciniata chromosome is 20 per cent larger than its $C$. aurea homologue. Meiotic pairing is extremely good so that homology can be established from the metaphase plates. From measurements made from camera lucida drawings of rod bivalents the difference in size between the homologues varies from 6 to 40 per cent which would indicate that the differences in chromosome size and DNA amount are not distributed equally to all the chromosomes of the complement. Fig. 3 also illustrates the type of configuration found in many of these hybrids. There are at least two translocations present in the C. laciniata $\times C$. aurea hybrid and probably a number of minor ones too, judging by the frequency with which multivalents occur. The incidence of ring multivalents is low, indicating that these translocations must be very unequal. The $C$. capillaris $\times C$. neglecta hybrid has a large number of cells containing trivalents so there is one substantial interchange present. Pairing is not as complete as in the C. laciniata $\times C$. aurea hybrid. 


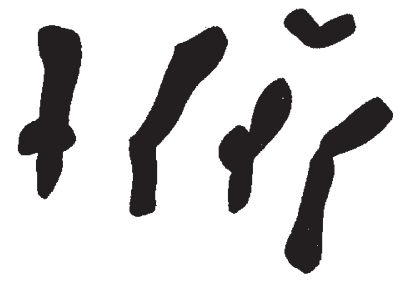

a

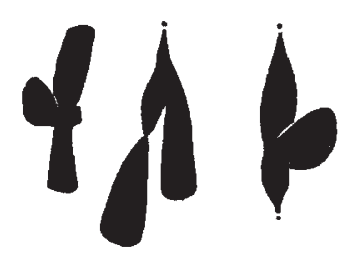

b

Fig. 3.-Metaphase I of meiosis in Crepis species hybrids. (a) C. laciniata $(2 n=2 x=8) \times$ C. aurea $(2 n=2 x=10)$. (b) C. capillaris $(2 n=2 x=6) \times$ C. neglecta $(2 n=2 x=8)$.

(iii) Direction of change during evolution

(a) Phylogeny and DNA. A subjective assessment of the evolutionary relationships of Crepis species can be obtained from Babcock (1947). The direction of change in DNA amount can be assessed by a correlation analysis of the DNA ranking and the taxonomic ranking (fig. 4). There is a significant negative correlation with a coefficient of $-0.56(\mathrm{P}<0.01)$. The most primitive, perennial species have more DNA than the advanced annual

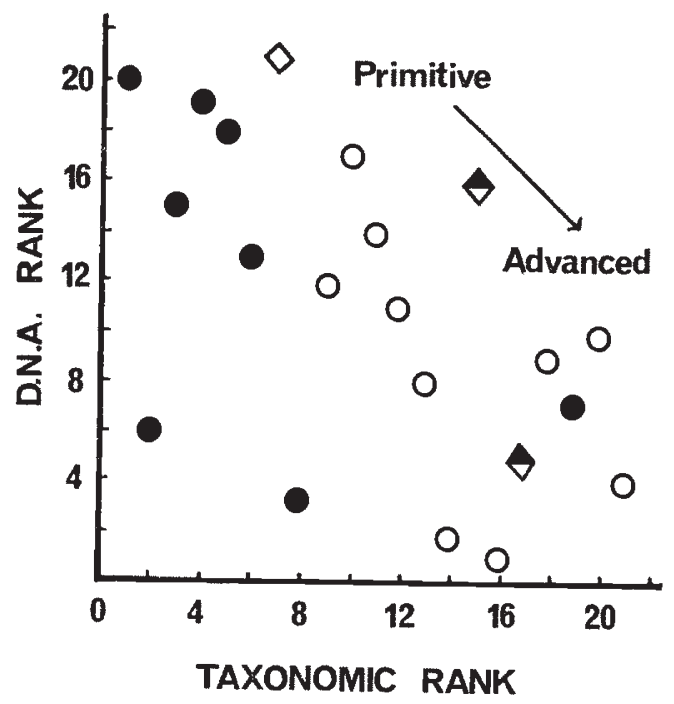

Fig. 4.-DNA ranking plotted against taxonomic ranking for 25 species of Crepis. $O$ annual, $\diamond$ biennial, $\diamond$ annual or biennial, 0 perennial. 
species. Thus there appears to have been a loss of DNA during evolutionary advancement of the genus.

(b) Chromosome asymmetry. Major changes in DNA amount are manifested in the morphology of the karyotype. Levitsky $(1931 a, b)$ first used the concept of chromosome asymmetry in describing karyotypes in terms of two parameters: the proportion of chromosomes with subterminal centromeres and the range of chromosome length. Stebbins (1958) states that there

TABLE 5

\begin{tabular}{|c|c|c|c|c|}
\hline Mean arm rat & f chromo. & e pairs. & $=\frac{\text { long }}{\text { short }}$ & \\
\hline Species & Rep. 1 & Rep. 2 & Mean & Variance \\
\hline$x=3$ & & & & \\
\hline${ }_{4}^{C .}$ capillaris & $4 \cdot 62$ & $4 \cdot 04$ & $4 \cdot 33$ & $4 \cdot 14$ \\
\hline C. dioscoridis & $4 \cdot 13$ & $4 \cdot 32$ & $4 \cdot 23$ & $2 \cdot 14$ \\
\hline C. palaestinia & $3 \cdot 26$ & $4 \cdot 65$ & 3.96 & $7 \cdot 92$ \\
\hline C. tectorum & $3 \cdot 26$ & $3 \cdot 15$ & $3 \cdot 21$ & 0.76 \\
\hline C. pulchra & $3 \cdot 12$ & $3 \cdot 21$ & $3 \cdot 17$ & 4.93 \\
\hline C. neglecta & $2 \cdot 77$ & $3 \cdot 27$ & $3 \cdot 02$ & $0 \cdot 20$ \\
\hline C. taraxacifolia & $3 \cdot 32$ & $2 \cdot 56$ & 2.94 & 0.61 \\
\hline C. laciniata & $3 \cdot 01$ & 2.74 & $2 \cdot 88$ & 0.39 \\
\hline C. setosa & $2 \cdot 58$ & $2 \cdot 58$ & $2 \cdot 58$ & 0.99 \\
\hline$x=5$ & & & & \\
\hline C. pontana & $2 \cdot 85$ & $2 \cdot 61$ & $2 \cdot 73$ & 1.38 \\
\hline C. sibirica & $2 \cdot 71$ & 2.58 & $2 \cdot 65$ & $1 \cdot 24$ \\
\hline C. alpina & $2 \cdot 31$ & $2 \cdot 29$ & $2 \cdot 30$ & 0.45 \\
\hline C. rubra & 1.94 & 1.98 & 1.96 & 0.93 \\
\hline C. aurea & 1.85 & $1 \cdot 70$ & 1.78 & 0.27 \\
\hline C. foetida & 1.55 & 1.56 & 1.56 & $0 \cdot 14$ \\
\hline
\end{tabular}

is a general trend towards asymmetry of karyotypes during evolution. That is, the karyotypes of advanced species show a larger proportion of subterminal centromeres and a greater diversity of chromosome length. The degree of asymmetry can be measured therefore in terms of mean arm ratio, the variance of arm ratios and the variance of chromosome lengths within species complements. As the amount of nuclear DNA has decreased during evolution, correlation of the above characters with DNA amount is a measure of the direction of karyotype evolution. The chromosome length data is given in table 4 and described above. The regression analysis of variance of chromosome length on to DNA amount is not significant. No conclusion can be drawn as to the direction of karyotype evolution in terms of chromosome length. Mean arm ratios (table 5) are significantly different for 15 species; the analysis of variance being significant at the 0.1 per cent level. As the difference between replicates is not significant the data was pooled. The joint regression analysis of variance of DNA amount against mean arm ratio for the two groups of species $(x=4, x=5)$ is highly significant $(\mathrm{P}<0.001)$. There is a strong positive correlation. With the diminution of nuclear DNA there has been a reduction of mean arm ratio. As the heterogeneity of regression item is not significant both groups show the same relationship between arm ratio and DNA amount. The difference between the means is not significant. The conclusion is that most advanced species have more chromosomes with median centromeres than the primitive species. As the 
means and variances of the arm ratios are positively correlated $(r=0.65$, $\mathbf{P}<0.01)$ the corrected variances were used. The joint regression analysis of variance of DNA amount against corrected variance is significant $(P<0.05)$. With a diminution in DNA amount there has been a decrease in the variance of arm ratios. The heterogeneity of regressions item is also significant $(\mathbf{P}<0.05)$ indicating that the rate of change of variance of arm ratios differs in the 4 and 5-chromosome groups of species. The difference between the means is not significant. The processes of unequal reciprocal translocation and pericentric inversion which have been paramount in the reduction of chromosome number in the genus have also, therefore, resulted in changes of chromosome symmetry. As Babcock and Jenkins (1943) have pointed out these operate, once an initial symmetry has been set up, in an opposite direction, this is towards asymmetry. The present analysis demonstrates, however, at least in terms of one of Levitsky's parameters, that the move has been towards symmetry rather than asymmetry.

\section{(iv) The consequences of nuclear variation}

A number of cell characters are influenced by the amount of nuclear DNA. The duration and rate of developmental processes, particularly meiosis and mitosis are also affected (Bennett, 1972). The size and mass of structures produced during development may also be, at least partially, dependent upon nuclear DNA amount. Pollen grains and seeds are convenient products of developmental processes for the examination of these effects in Crepis.

(a) Pollen grain size. The data is given in table 6 and each mean represents 12 pollen grain diameters given in arbitrary units. An analysis of variance of the data shows that there are significant differences between species. The quantity of nuclear DNA and the diameter of pollen grains are

TABle 6

\begin{tabular}{|c|c|c|}
\hline Species & Seed mass & Pollen diameter \\
\hline C. pontana & 0.3472 & - \\
\hline C. blattarioides & $0 \cdot 2206$ & - \\
\hline C. sibirica & $0 \cdot 1559$ & 一 \\
\hline C. grandiflora & $0 \cdot 1438$ & - \\
\hline C. canariensis & 0.0248 & - \\
\hline C. alpina & $0 \cdot 1005$ & $4 \cdot 08$ \\
\hline C. rubra & 0.0757 & $4 \cdot 10$ \\
\hline C. biennis & 0.0704 & $4 \cdot 67$ \\
\hline C. dioscoridis & 0.0670 & 4.53 \\
\hline C. aurea & 0.0385 & $4 \cdot 23$ \\
\hline C. foetida & 0.0376 & $3 \cdot 85$ \\
\hline C. pulchra & 0.0342 & $4 \cdot 05$ \\
\hline C. tectorum & 0.0228 & $3 \cdot 74$ \\
\hline C. setosa & 0.0164 & $3 \cdot 70$ \\
\hline C. taraxacifolia & $0 \cdot 0144$ & $3 \cdot 69$ \\
\hline C. capillaris & 0.0112 & $3 \cdot 47$ \\
\hline C. pannonica & - & $5 \cdot 29$ \\
\hline C. palaestinia & - & $4 \cdot 30$ \\
\hline C. zacintha & - & $3 \cdot 73$ \\
\hline
\end{tabular}


positively correlated. The regression is significant at the $0 \cdot 1$ per cent level. C. pannonica is the anomalous species.

(b) Seed weight. The seed mass data are also given in table 6. An analysis of variance shows that there are significant differences in seed weight between the species. The data are pooled over replicates for further analyses as the replicate means square is not significant. There is a significant positive regression between mean seed mass and nuclear DNA amount which is represented by the graph in fig. 5 . It has already been established that there

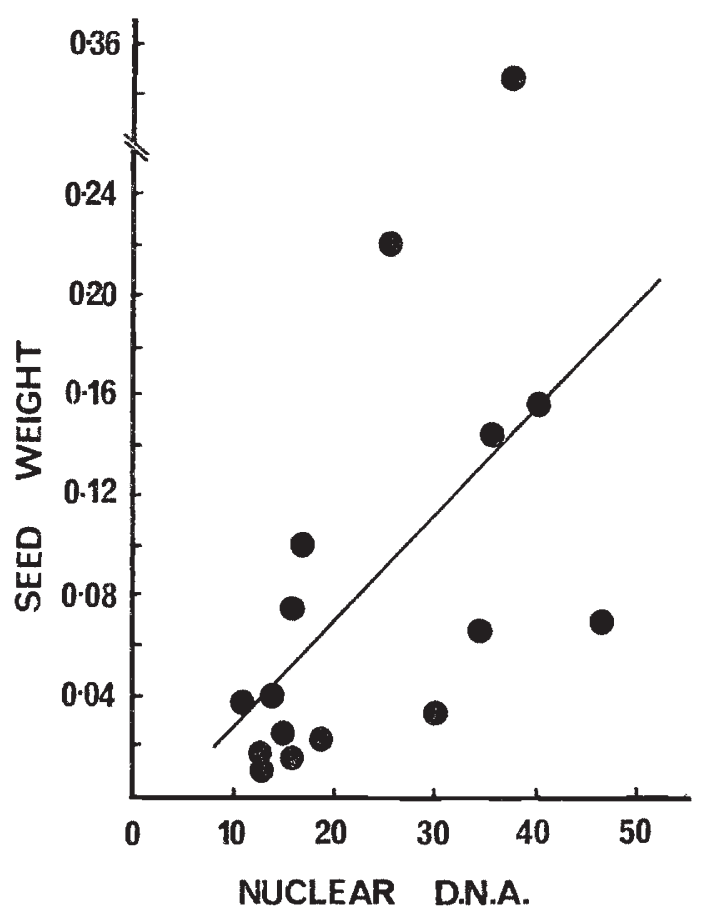

FIG. 5.-Mean seed weight (grams) plotted against mean nuclear DNA content (in arbitrary units) in 16 Crepis species.

has been a diminution of DNA during the evolutionary history of Crepis. Seed mass may be expected to be correlated with taxonomic advancement. The rank correlation coefficient is significant and positive $(r=0 \cdot 74$, $\mathrm{P}<0.001$ ). Primitive species of Crepis have larger seeds and more nuclear DNA than advanced species. A characteristic of achene morphology in this genus is the development of a beak during evolution as an aid to dispersal. The seed mass data form two separate groups according to the presence or absence of beaked achenes. Within each group there is a significant positive relationship between taxonomic rank and seed mass rank (fig. 6). The correlation coefficient of taxonomic and seed weight ranking for the beaked species is $0.95(\mathrm{P}<0.01)$ and for the non-beaked species is $0.78(\mathrm{P}<0.02)$. As $r$ values are not normally distributed these coefficients are transformed to $z$ values and are shown to be not significantly different $(P<0 \cdot 25)$. Both beaked and non-beaked seed weights are related to the level of taxonomic advancement in the same way. 


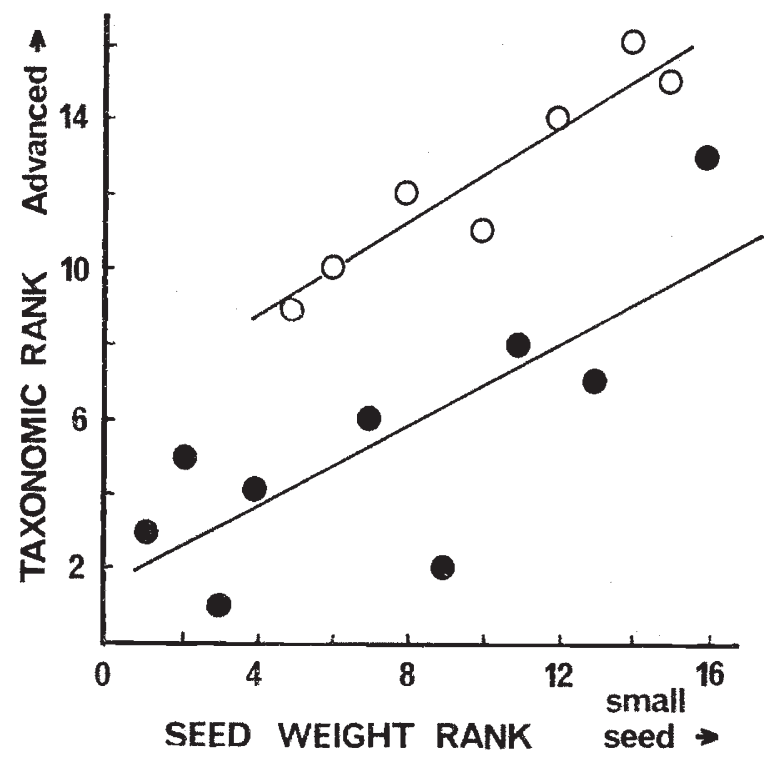

Fig. 6.-Taxonomic ranking plotted against seed weight ranking in 16 Crepis species. $O$ beaked seeds,

non-beaked seeds.

\section{Discussion}

There is a considerable range of nuclear DNA variation among the 25 Crepis species surveyed in the present study. Since these represent only a fraction of the 196 species known for the whole genus we might anticipate that the true extent of the variation is much larger than the 9-fold difference reported here. Compared to some other genera that have been surveyed, Anemone with a 5-fold variation (Rothfels, Sexsmith, Heimburger and Krause, 1966), Lathyrus 3-fold (Rees and Hazarika, 1969), Allium 3-fold (Jones and Rees, 1968), Vicia 6-fold (Chooi, 1971) and the Microseridinae subtribe of the Compositae $7 \cdot 7$-fold (Price and Bachman, 1975) the range is relatively large.

In Crepis we are dealing with a genus that has several different basic chromosome number groups within it, and we can readily point to one of the ways in which DNA variation can arise, i.e. by change in the number of chromosomes. Indeed Tobgy in 1943 described the way in which Crepis fuliginosa $(2 n=2 x=6)$ had been derived from C. neglecta $(2 n=2 x=8)$ by way of an unequal interchange and the loss of a small centric fragment. It is more difficult to explain how the variation in DNA amount has been achieved for those diploid species within the same basic chromosome number group. Certainly there is no suggestion of a geometric series of values compatible with polynemy, of the kind described for Anemone (Rothfels, Sexsmith, Heimburger and Krause, 1966) and Vicia (Martin, 1968). It has not been possible either to find any direct evidence, from pachytene analysis in species hybrids, of the large pairing loops found in the interspecific Allium hybrid by Jones and Rees (1968). Tobgy (1943) in fact considered the possibility that chromosome size differences in Crepis might have arisen as a result of the occurrence of large scale duplications and deletions, but rejected 
the idea through lack of evidence. Pachytene analysis of the species hybrids produced in the present study was, however, frustrated by the presence of multiple interchange and inversion complexes. The phenotype of the hybrid pachytene chromosomes was " difficult" to interpret and not so amenable to study as that of the parental species. The question still remains an open one as to whether the mechanism of DNA variation in Crepis involves duplications and deletions which are individually small and widely scattered throughout the length of the chromosomes, or whether they are in fact few in number, and large, as in Allium. Karyotype analysis certainly shows the DNA differences to be shared throughout all chromosomes of the complement.

One of the more interesting aspects of DNA variation in Crepis, as in Lathyrus (Rees and Hazarika, 1969) and the Microseridinae (Price and Bachman, 1975), is the finding of a negative correlation between nuclear DNA amount and the degree of evolutionary advancement. The direction of change, in general terms, is evidently towards smaller chromosomes, less DNA and in Crepis, towards a speeding up of developmental processes. It seems that the quantity of DNA present in the nucleus regulates such fundamental characters as cell size (pollen grains) and seed weight, quite independently of its informational content. The relatively advanced species of Crepis with the lowest DNA values, have the shortest life cycles and the smallest cells. Evolution of species within the genus has involved the "shedding" of quite a large fraction of the genome. The precise nature of the DNA lost during evolution and the manner in which it was reduced in quantity remain obscure. Some clue may be gained through a comparative qualitative analysis of the genome organisation of the species already described in this work.

\section{Referenaes}

BABCOCK, E. в. 1947. The genus Crepis. Univ. Calif. Publ. Bot., 21 and 22.

BABCOCK, E. B., AND COLlins, J. L. 1920. Interspecific hybrids in Crepis. I. C. capillaris (L.) Wallr. $\times$ C. tectorum L. Univ. Calif. Publ. Agric. Science, 2, 191-204.

вabcock, E. B., and Jenkins, J. A. 1943. Chromosomes and phylogeny in Crepis. Univ. Calif. Publ. Bot., 18, 241-291.

вabcock, E. B., and stebbins, G. L. 1943. Systematic studies in the Cichorieae. Univ. Calif. Publ. Bot., 18, 227-240.

BENNETT, M. D. 1972. Nuclear DNA content and minimum generation time in herbaceous plants. Proc. R. Soc. Lond. B., 181, 109-135.

BLACKBURN, K. B. 1933. Notes on the chromosomes of the duckweeds (Lemnaceae) introducing the question of chromosome size. Proc. Univ. Durham Philosophical Soc., 9, 84-90.

CHENG, R. I. J., AND GRANT, W. F. 1973. Species relationships in the Lotus corniculatus group as determined by karyotype and cytophotometric analyses. Can. F. Genet. Cytol., 15, $101-115$.

chool, w. Y. 1971. Variation in nuclear DNA content in the genus Vicia. Genetics, 68, 195-211.

Cullis, C. A., AND schweIzer, D. 1974. Repetitious DNA in some Anemone species. Chromosoma, 44, 417-421.

darlington, C. D. 1937. Recent Advances in Cytology, 2nd ed. J. and A. Churchill, London. GOEPFERT, D. 1975. Chromosome length values in digenomic buttercups (Ranunculaceae) and the relation to DNA content. Chromosoma, 49, 383-390.

Jones, R. N., AND REes, H. 1968. Nuclear DNA variation in Allium. Heredity, 23, 591-605. Levirsky, G. A. 1931a. The morphology of chromosomes. Bull. Appl. Bot. Genet. Plant Breed., 27, 19-174.

Levitsky, G. A. 1931b. The karyotype in systematics. Bull. Appl. Bot. Genet. Plant Breed., 27, 220-240. 
MCLEISH, J., AND SUNDERLAND, N. 1961. Measurements of deoxyribonucleic acid (DNA) in higher plants by Feulgen photometry and chemical methods. Exp. Cell Res., 24, 527-540. ManN, M. c. 1925. Chromosome number and individuality in the genus Crepis. I. A comparative study of the chromosome number and dimensions of nineteen species. Univ. Calif. Publ. Agric. Science, 2, 297-314.

MarTIN, P. G. 1968. Differences in chromosome size between related plant species. In Replication and Recombination of Genetic Material, ed. W. J. Peacock and A. D. Brock, 93-103. Australian Academy of Sciences, Canberra.

MIKsche, J. P., AND HOTTA, Y. 1973. DNA base composition and repetitious DNA in several conifers. Chromosoma, 41, 29-36.

PRICE, H. J., AND BACHMAN, K. 1975. DNA content and evolution in the Microseridinae. Amer. J. Bot., 62, 262-267.

REES, H., AND HAZARIKA, M. H. 1969. Chromosome evolution in Lathyrus. Chromosomes Today, 2, 158-165.

REES, H., AND JONES, R. N. 1972. The origin of the wide species variation in nuclear DNA content. Int. Rev. Cytol., 32, 53-92.

Rothfels, K., SEXSMith, E., heIMburger, M., AND krause, M. o. 1966. Chromosome size and DNA content of species of Anemone $\mathbf{L}$. and related genera (Ranunculaceae). Chromosoma, $20,54-74$.

SPARROW, A. H., PRICE, H. J., AND UNDERBRINK, A. G. 1972. A survey of DNA content per cell and per chromosome of prokaryotic and eukaryotic organisms: some evolutionary considerations. Brookhaven Symp. in Biol., 23, 451-494.

STEBrins, G. L. 1958. Longevity, habitat and release of genetic variability in the higher plants. Cold Spring Harb. Symp. Quant. Biol., 23, 365-377.

TOBGY, H. A. 1943. A cytological study of Crepis fuliginosa, $C$. neglecta and their $\mathrm{F}_{1}$ hybrid and its bearing on the mechanism of phylogenetic reduction in chromosome number. 7. Genet., 45, 67-111. 